\title{
Sevme Sanatı Olarak Felsefe
}

\section{MELIKE MOLACl ${ }^{1}$}

\author{
${ }^{1}$ Asst. Prof. Dr., Necmettin Erbakan University, Department of Philosophy \\ (Orcid ID: 0000-0002-8128-7706)
}

\begin{abstract}
Özet
Bilgeliğin sözle değil eylemle edinildiğini düşünen Stoacılar, felsefeyi yaşama sanatı olarak tanımlarlar. Stoacı bilgenin doğaya uygun eylemleriyle bir sanat eserine dönüştürdüğü yaşamı, dingin ve çetin bir ruhu gerektirir. Yanılgılardan ve tutkulardan uzak bilgece yaşamın bir sanat eseri olarak düşünülmesi ilk bakışta mümkün görünmeyebilir. Günümüz ayrımlarıyla yaklaşıldığında Stoa felsefesinde estetik yaşantının özerk olmadığı ve estetiğin müstakil bir disiplin olarak kuramsallaştırımadığı da rahatlıkla söylenebilir. Bununla birlikte güncel ayrımlar ve kavramlarla Antikçağ kuramlarına yaklaşmak, kestirme ve yanlış sonuçlara neden olabilir. Bu tehlikenin bertaraf edilebilmesi ve yaşama sanatının tam da Stoacıların iddia ettiği gibi estetik ve politik bir yaşama işaret ettiğinin temellendirilebilmesi için ilk kaynaklara, erken dönem Stoacı filozoflara dönülmelidir. Estetik, etik ve politik bir yaşamın Stoacı yaşama sanatında içerildiği iddiasında olan bu çalışmada, felsefeyle yakından ilişkili olan "sevme sanatı"na odaklanılmaktadır. Çünkü Stoacı yaşama sanatı halen rağbet görmesine rağmen-, çağdaş yazarların kapsamlı incelemelerine konu; özgün kuramlarına da ilham olan "eski" bir meseledir. Oysa tutkusuz bilgenin sevme sanatındaki ustalığı, oldukça dikkat çekici özellikleri açığa çıkarır ve çeşitli olanakları tartışmayı sağlar. Bu nedenle bu yazıda erken dönem Stoa felsefesinin sevme sanatı olarak adlandırdığı ilişki biçimi ile bu sanatın yetkinliği olan sevme erdemi ele alınmakta; bunlar aracılığıla Stoacıların etik, estetik ve politik bir yaşamı bir arada nasıl düşünebildikleri incelenmektedir.
\end{abstract}

Anahtar Kelimeler: stoacılık, aşk, yaşama sanatı, sevme sanatı, sevme erdemi. 


\title{
Philosophy as the Art of Loving
}

\begin{abstract}
The Stoics who think that wisdom is achieved by practice, not by words, define philosophy as the art of living. The life of the Stoic sage, which he transforms into the artwork with his actions according to nature, requires a calm and an austere soul. At first glance, it may not seem possible to think that a sage life is an artwork, removed from mistakes and passions. When approached with current distinctions, it can be easily said that aesthetic life is not autonomous in Stoicism, and aesthetics is not theorized as an independent discipline. However, approaching ancient theories with current distinctions and concepts may lead to shorthand and deficient consequences. To eliminate this threat and justify that the art of living points to an aesthetic and a political life exactly as the Stoics claim, it is necessary to turn to the primary sources, the old Stoics. This study, which claims that an aesthetic, ethical, and a political life is included in the art of living, focuses on "the art of loving", which is closely related to philosophy. Because the art of living - although still in demand - is an "out of date" issue that is still the subject of a comprehensive study by contemporary writers and inspires their original theories. However, the art of loving that passionless sage has, reveals remarkable features and enables discussion of various possibilities. For this reason, in this article, the relationship form that the early Stoicism called the art of loving and the erotic virtue, which is the perfection of this art, are discussed; and through these, it is examined how the Stoics could conceive an ethical, aesthetic and a political life together.
\end{abstract}

Key Words: Stoicism, love, the art of living, the art of loving, erotic virtue.

Corresponding Author / Sorumlu Yazar

E-mail / E-posta

Manuscript Received / Gönderim Tarihi

Revised Manuscript Accepted / Kabul Tarihi

To Cite This Article / Kaynak Göster
MELIKE MOLACI

Necmettin Erbakan University, Department of

Philosophy, Asst. Prof. Dr.

melikemolacı@gmail.com

Jan 10, 2021/ 10 Ocak 2021

Mar 22, 2021 / 22 Mart 2021

Molacı, M. (2021). Sevme Sanatı Olarak Felsefe

ViraVerita E-Journal: Interdisciplinary Encounters,

Vol.13, 12-33. 


\section{Sevme Sanatı Olarak Felsefe}

\section{Giriş}

Felsefeyi "yaşama sanatı" olarak tanımlayan' ve çeşitli alıştırmalar aracılığıyla bu sanatın ustası olmaya aday olanlara iyi ve mutlu bir yaşam vaat eden Stoacılık, yaşamın estetik olarak kavranmasına yönelik talimatlar içeren pek çok reçete sunar. Felsefenin sanat olarak ele alınması, aklın doğru şekilde kullanılması ile doğaya yönelik teorilerin temellendirilmesini gerektirdiği kadar yargıların düzenlenmesi, ruhun sağaltımı ve tutkuların çözümlenmesi gibi birtakım prosedürler içerir. Yaşama sanatı olarak felsefe, nasıl davranılacağını bilmeyi, gerektiğinde kendini teselli etmeyi, herhangi bir acı ya da talihsizlikle karşılaşıldığında doğru düşünmeyi ve uygun eylemeyi içerir. Çağdaş yazarların "kendilik teknikleri", "tutkuların terapisi" ya da "spritüel alıştırmalar" olarak da adlandırdıkları" bütün bu pratikler, özellikle geç dönem Stoacı filozofların metinleri aracılığıyla temellendirilir. Romalı Stoacıların kendini incelemeyi, yargıları düzenlemeyi ve tutkuları dışlamayı içeren öznel talimleri, sıklıkla belirli bir ana ya da özel bir duruma ilişkin görünse de, bu filozofların asli amacı genel bir varoluş tarzının inşasıdır. Stoacı bilgenin magnum opus'u olan felsefi yaşamı, tamamıyla gerçek, iyi ve güzel olan tek yaşamdır; bu yaşam aynı zamanda özgür bir özne olan bilgenin politik varlığının da teminatıdır. Nitekim Stoacılar için aynı zamanda erdem alıştırmasına karşılık gelen yaşama sanatı, "doğası gereği politik ve rasyonel olan canlının iyileriyle ilgilidir" (Stobaei, 1909, s. 57-8). Bu haliyle kişinin ruhsal alıştırmalarla yerleşen akla uygun davranışları ve bunların sonucunda ortaya çıkan yükümlülükleri, öznellikten nesnelliğe, tekil var oluştan dünya yurttaşlığına uzanan etik, politik ve estetik bir yaşamı mümkün kılmaktadır.

Bilgenin sanat eserine karşılık gelen yaşamı, sarsılmaz bir ruha ve mutlak bir dinginliğe sahip olmayı içerir; bilgenin ruhu yanılgılardan ve tutkulardan uzaktır. Fakat bu yoksunluk, yaşamın estetik kavranışına ve yaşama sanatı olarak felsefenin beyhudeliğine dair birtakım sorunlar doğurur. Stoa felsefesinde güzelin gerçek, iyi, uygun, yararlı ve kullanışlı olan ile özdeş olarak düşünülmesi (Stobaei, 1909, p. 100), estetiğin özerkliğini şüpheli hale getirir. Bu durum Nietzsche'nin Stoa ahlakının işlevselliğine dair eleştirisinde de açıkça dile getirilir: "Stoacılar onun [Herakleitos] âlemi oyun olarak gören estetik görüşünü, âlemde insanın faydasını göz önünde tutan, amaca uygunluk gibi adi bir seviyeye indirmişlerdir" (2010, s. 72). Nietzsche'ye göre "Yunan giysilerine ve kavramlarına sarılmış bir Arap şeyhi" (1968, p. 115) olan Stoacının 
kurallara bağlı ve her koşulda akla itaat etmeyi buyuran yaşamı, estetik olmak bir yana sert ve zorba bir ahlakın boyunduruğunda süren çileci ve kölece bir yaşamdır (1968, p. 153; 188; 232; 384). Stoacıların estetiği çiğ bir ahlakçılığa indirgediğini düşünen Nietzsche'nin vurguladığı bu problem, "Stoacı paradokslar"dan biri olarak Cicero tarafından da tartışılır. Cicero "sadece güzel olan (to kalon) iyidir" olarak ifade edilen paradoksta güzel olanı "asil ya da ahlaki açıdan değerli olan (honestum)" ile karşılar. Bu haliyle iyi olan (bonum), erdemli (virtus), asil (honestus) ve doğru olan (rectum) anlamına gelir (Cicero, 2012, VI-IX). Fakat bu döngüsel tanımlar Romalı Stoacılar için olduğu gibi Cicero'da da herhangi bir sorun teşkil etmez.

Etik ve politik bağlamda bilgeye özgü bir nitelik ve iyinin pek çok adından biri olan güzel, Stoa kozmolojisinde uyumla (harmonia) ve işlevine uygunlukla (homologia) birlikte düşünülür ve teknik kullanımıyla simetri (symmetria) olarak adlandırılır (Galen, 2005, V.3.15; Stobaei, 1909, p. 63). Evrensel uyum olarak güzel, tekiller düzleminde işleve uygunluk ya da yetkinlik olarak yapılan erdem tanımında yinelenir (Laertius, 1931, VII. 89-90) ve güzele dair Stoacı kavramsallaştırma döngüsellikle sonuçlanır. Kuşkusuz bu döngüsellik Stoacıların büyük değer atfettikleri erdem ve aklın, felsefenin bütün alanlarında belirleyici olmasından kaynaklanır. Oysa bu ve buna benzer pek çok paradoks, Stoa epistemolojisi ve ontolojisi aracılığıyla temellendirilebilir. Stoa felsefesinde eylemi belirleyen tercihlerin yalnızca akla dayanması ve yargı biçiminde ifade edilen tutkulara hiçbir koşulda onay verilmemesi, öznenin “özü”nün akıl olduğunu gösterir. Benzer bir biçimde imgelemin epistemolojik ve ontolojik açıdan değersizliği ile imgelerin (phantasma) sahteliğine yapılan Stoacı vurgu (Laertius, 1931, VII. 50), estetik yaşantıyla imgelem arasındaki asli ilişkiyi vurgulayan sanat tanımlarının, Stoacılar için muteber olmaması anlamına gelir. Sanatın bilgiye dayalı tanımları ve erdem gibi kavramların tanımlanmasında tekhnē ile epistēmē'nin bazı bakımlardan örtüşmesi de (Stobaei, 1909, p. 58), sanatın doğrudan akılla ilişkilendirildiğini gösterir. Son tahlilde Stoacıların imgeleri değersiz gören, tutkuları lağveden ve güzeli iyiye indirgeyen kuramları, günümüzde sanattan ve estetikten anlaşılana pek de benzemez.

Bu noktada Stoacıların "indirgemeci", "döngüsel" ve "paradoksal” görüşlerinde açığa çıkan "tutkusuz" bir sanatın, yaşama sanatı olarak felsefe anlayışılla nasıl uzlaşabildiğini anlamak güçleşir. Kuşkusuz günümüzde felsefeyi yaşama sanatı olarak düşünmenin bir yolu tekhnē ile ars arasındaki ayrımı keskinleştirmekten geçer; zanaatı sanattan ayırmak, belli ölçüde probleme bir cevap vermeyi sağlayabilir. Fakat günümüzün sanat felsefesi ve estetiğe dair kavramlarıyla Stoacı tekhnē anlayışını değerlendirmeye çalışmak anakronizm içerir ve Stoacı 
yaşama sanatına dair kestirme cevaplara neden olur. Çünkü Stoa felsefesinde zanaat sanattan, sanat da bilimden öyle kolayca ayrılamaz. Yaşama sanatıyla özdeş olan erdemli yaşamın muhtelif erdemleri, "pratik bilgeliğe (phronēsis)" göre tanımlanan ve yalnızca konusu bakımından birbirinden farklılaşan yetkinlikler (Stobaei, 1909, p. 60-1) olarak düşünülürler. Bu haliyle Stoacı yaşama sanatı sophia'ya değil, phronēsis'e dayanır; akıldan, bilgiden ve eylemden ayrı düşünülmez.

Ayrıca Antikçağ yazarlarının tekhnē'yi erek ve etkinlik bakımından iki türe ayıran sınıflandırmaları (Platon, 1925, 56a-e; Aristoteles, 1995, 1355b; 2007, 101b; 160a) da Stoacı yaşama sanatını belirginleştirme noktasında yetersiz kalır. Antikçağ’ın doktorluk ve kaptanlık gibi talihle (tykhē) de ilgili olan stokhastik tekhne’’leri ya da mimarlık ve marangozluk gibi erekle etkinliğin örtüştüğü uzmanlıkları, Stoacı yaşama sanatıyla ilgisizdir. Stoacı yaşama sanatı, ne marangozluk gibi bir zanaata ne heykeltıraşlık gibi bir sanata ne de bilgi ve alıştırmaya bağlı olan doktorluk gibi bir uzmanlığa benzer. Çünkü bu sanatlarda etkinlik ile ereğin örtüşüp örtüşmemesinin yanı sıra, yaratan (sanatçı) ile yaratılan (eser) da birbirinden farklıdır. Oysa Stoacı yaşama sanatında etkinlikle ereğin örtüşmesi, özne ile nesne arasındaki ayrımın silikleşmesi anlamına gelir. Özellikle erken dönem Stoacı yaşama sanatının asli malzemesi sanatçının kendisidir, bu nedenle yaratan ile yaratılanın ilkesi birdir. Orta ve geç dönem Stoacılar, etkinlikle ereğin her zaman örtüşmeyeceğini düşünseler de yaşama sanatını bir güreşçinin ya da atletin, idmanı, öz disiplini ve sezgiyi gerektiren etkinliğine benzettiklerinde (Epiktetos, 2019, XXXIX; Aurelius, 1930, VII. 61) ya da erken dönem Stoacılar dans gibi performansa dayalı olan bir etkinliği yaşama sanatı için bir örnek olarak sunduklarında (Cicero, 1931, III. 24), özne ile nesnenin birlikteliğini vurgulamak isterler. Burada atletin, güreşçinin ya da dansçının kendinden başka bir araçla sanatını icra etmemesi ve etkinliğin bizzat sanatçıyla örtüşmesi, icracıdan ayrı bir eserin olanaksızlığını gösterir. Bunun yanı sıra performatif sanatlarda etkinlikten ayrı bir erek de söz konusu olmadığı için, geleneksel ayrımların yaşama sanatının ne olduğunu belirginleştirmeleri mümkün değildir.

Stoacıların sanata ilişkin kuramlarında ve estetik kavrayışlarında ortaya çıkan bu problemler, Antikçağ yazarları için olduğu kadar pek çok çağdaş araştırmacı için de önemli bir tartışma konusu olmuştur. Çağdaş literatür bu paradoksal duruma ilişkin çok sayıda çözüm önerisi sunar.iii Stoacılar için sanatın ve imgenin değeri, tutkuların ve aklın konumu, güzelin ve aşkın farkı bağlamlarda farklı şekillerde tanımlanıp ilişkilendirildiği çalışmalar, problemin farklı şekillerde ele alınabileceğini gösterirken, bu çeşitlilik bir sonuca varabilmek için bir seçim 
yapmayı da zorunlu kılar. Yapılacak seçim, kestirme cevapların önüne geçmeyi sağlayabileceği gibi Stoacıların "tutkusuzluk" ile işaretlenen tutumlarının içerdiği politik olanakları da düşünmeyi sağlar. Bu noktada etik ile estetik, sanat ile felsefe arasındaki çetrefilli ilişkiye dair soruşturma için Antik kaynakların Stoacılığa yönelttiği eleştirileri incelemek kullanışlı bir hareket noktası olarak görünür ve muhalif kaynaklar, sorunu ilk elden belirlemeye yardımcı olurlar.

\section{Yaşama Sanatı ve Konuları}

Sextus Empiricus felsefenin ahlak kısmı üzerine olan incelemesinde, Stoacılar için ruhtaki iyilerin bir kısmının sanat olduğunu belirttikten sonra, genel olarak sanatın olanaklı olup olmadığını tartışmaya başlar. Oldukça teknik olan problemlerin ele alındığı bu bölümde, bu konular hakkında bilgi sahibi olmanın ve yargıda bulunmanın olanaksız olduğu Skeptik öncüllerle temellendirilir ve hemen ardından yaşama sanatı incelenmeye başlanır. Bu sanatın eleştiri konusu olan dogmatik görüşleri büyük ölçüde Stoacı düşüncelere dayanır ve Sextus Empiricus Stoacıların yaşama sanatıyla ilgili kitaplarında geçen konulardan örnekler sunar. Burada çocukların eğitimi, ebeveyne hürmet, birlikte yaşama kuralları, beslenme düzeni gibi hem toplumsal hem de bireysel davranış kalıplarına değinildiği görülür (1933, III.188-250). Yine Diogenes Laertios'un Skeptik Cassius ve hatip İsidoros'a dayandırdığı aktarımında Zenon'un temel eğitime karşı, aile üyelerine düşman, devlete ve kurumlarına muhalif, kişiler arası geleneksel ilişkileri ters yüz eden fikirlere sahip olduğu da ileri sürülür (1931, VII. 32-4).

Stoacılığa muhalif yazarların bu konuları dayandırdığı eserlerin adları ise oldukça ilgi çekici bir bağlantıyı açığa çıkarır. Eleştirilerin kaynağı olan kitaplardan Devlet ve Sevme Sanatı (Erōtikē Tekhnē) Zenon'a; Devlet Üzerine ve Aşk Üzerine (Peri Eratōs) ise Khrysippos'a atfedilir (Laertius, 1931, VII. 32-4; 130; 188; Empiricus, 1933, III. 245-6). Bununla birlikte yaşama sanatıyla ilgili doğrudan atıf yapılmasa da Kleanthes'in Aşk Üzerine, Devlet Üzerine, Sevme Sanatı Üzerine ve Şölen Üzerine adlı eserlerinin (Laertius, 1931, VII. 175) de bu konularla ilgili olması oldukça muhtemeldir. Zira Pearson, Plutarkhos'un Kleanthes'e dair aktarımında bahsi geçen aşk konusunun, Zenon'un Sevme Sanatı kitabıyla ilgili olduğunu vurgular (1891, p. 323). Yine Diogenes Laertios'un kataloglarında (1931, VII. 4; 78; 129; 136; 163; 175; 178; 199-202) ve Arnim'in koleksiyonunda (1964, I, p. 71; 137-9; III. p. 194-205) görüldüğü kadarıyla neredeyse her erken dönem Stoacının devlet, aşk ve dostlukla ilgili bir kitap yazmış olması ve bu eserlerde aşk ile politikayı birlikte düşünmüş olmaları muhtemeldir. Aşk ile politikanın birbiriyle 
ilişkilendirilmesinin asli nedeni Schofield'in da Stoacı "evrensel devlet (cosmic city)" anlayışını temellendirmek için uzun uzadıya tartıştığı (1999, p. 27-56) bir pasajdır:

Pontianos, Kitionlu Zenon'un Aşkı bir tanrı olarak düşündüğünü ve onun dostluk (philia), uyum (homonoia) ve özgürlükten (eleutheria) başka bir şeyle ilgili olmadığını söyler. Ayrıca Devlet’te söylediğine göre Aşk, devletin güvenliğini/ istikrarını (sōtēria) sağlamaya yardımcı olan bir tanrıdır. Zenon'un Aşkı bayağı her şeyden ayırdığı ve kutsal bir varlık olarak düşündüğü de bilinir; zaten gymnasiumlarda aklın (logos) ilk taşıyıcısı Hermes ile gücün (alkē) sembolü Herakles'in yanı başına dikilen Eros heykeli bir birlik oluşturur. Dostluk ve uyum onlardan doğar, [....] bunun anlamı en yüce özgürlüğün (kallistē eleutheria) buradan filizlenmesidir (Athenaeus, 1927, 561c-d).

Athenaios'a ait bu alıntı, Stoacı yaşama sanatının hem politik hem de erotik olduğunu gösterir ve onu "sevme sanatı (erōtikē tekhnē)" olarak düşünmeye olanak sağlar. Ayrıca aşk ile özgürlük arasındaki bağlantı Foucault'nun ars erotica olarak adlandırdığı (2010, s. 48) pratikleri de anlaşılır kılar. Stoacılık söz konusu olduğunda Foucault geç dönem Stoacı metinlere odaklanıp asketik pratikleri kendilik ile ilişkilendirir, fakat erken dönem Stoacıların sevme sanatıyla ilgili düşüncelerine yeterince değinmez. Oysa erken dönemde aşk, Roma Stoacılığına nazaran çok daha asli bir konudur, yaşam ve politikayla da yakından ilgilidir. Bu bağlantılardan hareketle Stoacı yaşama sanatının, sevme sanatı olarak düşünülmesi mümkündür ve bu sanatın yetkinliği olan "sevme erdemi (erōtikē)"nin de bu ilişkiyi aydınlatması olasıdır.

Antik Yunan toplumunda bir eğitim aracı olarak düşünülen aşk önemli bir araştırma konusudur; onun ne olduğu, nasıl yaşanacağı, sevenin (erastēs) ve sevilenin (eromenos) hangi niteliklere sahip olması gerektiği gibi hususlar araştırmanın ana başlıklarıdır. Bu bağlamda Stoa etiğinde erdem türlerinden biri olarak anılan ve "güzelce (asilce) sevme bilgisi (epistēmēn toū kalōs erān)" olarak tanımlanan (Stobaei, 1909, p. 66) sevme erdemi, şölenlerde nasıl davranılması gerektiğinin bilgisiyle birlikte sevenin karakterini (ethos) de ifade eder. Sevme sanatının ehli olanlara özgü olan bu erdem, sevenin sevilene nasıl yönelmesi gerektiğini ve bu ilişkide yönlendirici olan aşkın doğasını incelemeyi gerektirir. Bununla birlikte oldukça kapsamlı bir araştırmayı gerektiren ve okul tarihinde birbiriyle çelişen görüşlerin ileri sürüldüğü bu konunun müstakil erdeminin, erken dönem Stoacılığa özgü olduğu belirtilmelidir. Okulun ilerleyen dönemlerinde aşkın pedagojik bir araç olmaktan çıkması, şölen geleneğinin ortadan kalkmış olması ve Roma toplumunda evliliğin yüceltilmesiv gibi hususlar, sevme erdemini erken dönemle sınırlandırmayı gerektirir. Zira Seneca’da aşkın, erdem ile mutluluğa katkı sağlayan 
özgürleştirici yanları göz ardı edilir ve o, ruhtan mutlaka sökülüp atılması gereken bir tutku olarak düşünülür (1928, I. 7; II. 2-6). v Sevme erdemiyle ilgili olarak Seneca, "gençleri kaç yaşına kadar sevebiliriz diye araştırma yapmanın" Yunan âdeti olduğunu söyler ve Roma'da bunlar hakkında araştırma yapanların Stoa felsefesinin eteklerine sığınmış sözde filozoflar olduklarını düşünür $(1925,123.15-16)$. Aşkın patolojik doğası Epiktetos tarafından da kınanır; O, özgür ve erdemli bir yaşam için aşk yerine yakınlığı (storge) vurgular ve bilgenin âşık değil müşfik (philostorgos) olduğunu ekler (1998, I. 23. 3; II. 14. 7-8). Marcus Aurelius hata yapan insanları bile sevmenin (philia) insana özgü olduğunu belirtirken aşkı hiç anmaz; burada kozmik sempatinin bağlayıcılığıyla birlikte insanları akraba (syngenēs) kılan aklın üstünlüğü vurgulanır (1930, VII. 22). Oysa aşktan akrabalığa evrilen bu düşünce sürecinde erken dönem Stoacılar aşkı ve yetkin aşığı çeşitli gerekçelerle överler, aşka ve sevme erdemine de pedagojik açıdan özel bir önem atfederler.

Konu sevme erdemi ve sevme sanatıyla, dönem de erken dönemle sınırlandırıldığında, Stoacılar için estetik bir yaşamın politik ve etik bir yaşam olarak düşünülmesinin ne anlama geldiği açıkça tartışılabilir. Fakat bunun için öncelikle erken dönem Stoacıların aşka ve -aşkla ilgisinde- güzele dair yapmış oldukları ayrımlara değinilmeli; ardından seven ile sevilen arasındaki ilişkide sergilenen sevme erdeminin ne olduğu ve hangi probleme cevap vermek için ileri sürüldüğü belirginleştirilmelidir. Böylece sevme sanatında ehil olanların gerçekten estetik ve politik bir yaşamın öznesi olup olamayacaklarına dair bir sonuca varılabileceği gibi, Stoacıların çiğ bir ahlakçılık adına güzelin, uyumun ve aşkın anlamını bulanıklaştırıp bulanıklaştırmadıkları da anlaşıllabilir.

\section{Üç Başlı Aşk}

Antikçağ şölenlerinin asli konusu olan aşkın ve onun nesnesi olan güzelin ne olduğu konusunda farklı görüşlere rastlanır. Bunların arasında erken dönem Stoacıların takip ettikleri ya da reddettikleri üç görüş dikkat çekicidir: Aşk bazen güzelin peşinde olan bir daimon (Platon, 2014, 203a-e), bazen tanrı vergisi bir çılgınlık (Platon, 2019, 251a-253b), bazen de yöneldiği nesnenin doğasına uygun olarak göksel ya da yersel olarak ikiye ayrılan bir şey olarak düşünülür (Platon 2014, 180d-182d; Xenophon, 1997, VIII. 10-12). Erken dönem Stoa etiğinde aşkın ikinci tanımı koşulsuz olarak reddedilir, diğer ikisi ise Stoacı aşkın ilk bakışta birbiriyle uzlaşmaz görünen üç ayrı tanımında yinelenir. Stoacıların reddettikleri ikinci tanım, ruhun akıldışı bir bölümü olmadığına dair kabulün sonucudur. Ruhta birbiriyle mücadele eden bölümlerin bulunması 
Stoacılar için bir çelişki olduğu için (Seneca, 1928, I. 10), aşkın da dâhil olduğu bütün tutkular, doğaya ve akla aykırı devinimler olarak tanımlanmakta ve son tahlilde yargı (krisis) ya da sanı (doksa) olarak düşünülmektedirler (Laertius, 1931, VII. 110-111; Stobaei, 1909, p. 88). Dahası Stoacılar için aşkın kişinin gücünü aşması ve onu edilgen bir alıcı konumuna yerleştirmesi, kişinin gücü dâhilinde olan erdemli yaşamın olanaksız olmasına yol açar. Talihe ya da şansa bağlı her türlü oluşu reddeden Stoacılar, hiçbir tutkunun istemsizce ruha sızmasına izin vermezler: “Khrysippos’un Aşk Üzerine adlı eserinde söylediği gibi, aşk [...] tanrılar tarafından gönderilmiş bir şey değildir (mè einai theopempton)"(Laertius, 1931, VII. 130).

Aşkın kişiyi edilgen kılan bir tutku olmadığı kabul edildiğinde psikolojik, etik ya da politik bağlamlarda dile getirilmiş üç farklı türsel tanımla karşılaşılır. Tür bakımından "kötü", "iyi" ve "farksız" olarak yapılan ayrım, işlev bakımından aşkın "patolojik", "politik" ve "pedagojik" olarak sınıflandırılmasına olanak sağlar. "Kötü" ya da "patolojik" anlamıyla aşk, nesnesi beden, beklentisi cinsel birleşme olan bir arzu iken, "iyi" ya da "politik" olan aşkın nesnesi ruhtur ve o kendinde dostluktur (philia) (Arnim, 1964, III. 180-1; Laertius, 1931, VII. 113; 130; Stobaei, 1909, p. 91). Aşkın "pedagojik" işlevini vurgulayan son ayrımda onun erdeme katkı sağlamak üzere tercih edilen bir "farksız (adiaphoros)" olduğu da ifade edilir (Stobaei, 1909, p. 66).

Aşkın "iyi" ve "kötü" anlamları Şölen'lerde bahsi geçen yersel-göksel ayrımını devam ettirirken bunun asli nedeni Stoacıların geleneğe sadakatleridir. Fakat bu sadakat, Aphrodite'nin doğuşuyla ilgili olarak Theogoni'de ifade edilenlerin ötesine uzanır. Stoacı alegorist Kornoutos Aşk tanrısı hakkında konuşurken ilkin onu bir çocuk olarak betimler; burada âşıkların olgunlaşmamış düşünceleri ve tutarsız davranışları aşkın uçucu (kanatlı) doğasıyla ilişkilendirilir. Eros'un oku ve meşalesi ruhta aniden tutuşan aşk ateşini simgeler. Aşkın bu hali hasret (himeros) ve özlem (pothos) olarak da adlandırılır ve o aynı zamanda kişiyi aptallaştırır (memōrōsthai). Aşkın Phaidros'ta geçen tasvirini anımsatan ve Stoacıların kabul etmeyeceği bu aktarımların ardından Kornoutos, bazılarının aşkı başka şekilde düşündüklerini belirtir:

Aşk, evrenin bütünüdür: Güzel, çekici ve gençtir, ateşle dolu [aşk], bir anda olup biten hareketin nedeni olduğu içindir ki, o var olanların en eskisidir [....] Ayrıca onun 'Atlas' olduğunu da söylerler, çünkü o hiç yorulmaz (atalaipōrōs), her şeyi kuşatan ve [göğü bile] bir arada tutan ilkelerin kaynağı odur. Aşağı ve yukarı doğru olan hareketi yöneten, göğe ve yere hükmeden öğelerin güçleri ondan gelir. Atlas bilgedir (holōphron) ayrıca; bütünü gözetir (holōn phrontizō) ve parçaların istikrarına (sōtēria) öngörüsüyle (pronoeō) hükmeder (Cornutus, 2018, 25. 48). 
Kornoutos'un bu aktarımında aşkın hem genç hem de yaşlı olarak düşünülmesi Stoa eskatolojisinin "büyük tutuşma (ekyprōsis)" doktriniyle ilgilidir. Bu haliyle ateşle dolu aşk, Stoacıların yaratıcı ve yok edici unsuru olan ateşle bir tutulur. Başlangıcı olmayan etkin ateş, sonsuza kadar evreni var eder ve yok eder; bitimsiz olan bu döngüde aşk her daim eski ve hep yenidir. Stoacıların Eros ile Atlas'ı özdeşleştirmeleri ise -yukarıda anılan- Athenaios'a ait pasajı doğrular. Aşkın özgürlük, uyum ve istikrarla olan ilişkisinin yanı sıra varlıkları bir arada tutan rasyonel bir düzen ilkesi olarak tasvir edilmesi, Stoacıların aşkı "kozmik" bir güç olarak da düşündüklerini gösterir. Evrensel açıdan düşünüldüğünde aşk, tıpkı logos gibi evreni kuşatır. Onun ateşli doğası oluş kadar yok oluşa da neden olur. Bu haliyle kozmik aşkın yok ediciliğinin zorunluluğu, beşeri düzlemde "kötü" aşkın doğasını açıklamaya yarar. Bir bütün olarak evrenin ya da evrendeki herhangi bir var olanın yok oluşu, bir kötülük olmasa da, aşk akla aykırı bir yargı olduğunda ruh dinginliğini yok eden bir kötülük anlamına gelir. Kozmik ve beşeri yok oluşun ahlaki açıdan farklılaşması ise aşka dair üçüncü ayrıma ulaştırır.

Diotima'nın bir daimon olarak tasvir ettiği Eros'un arada bulunan konumunu çağrıştıran üçüncü ayrımda aşk, bir farksız olarak tanımlanır. Farksız aşk, kozmik ve beşeri perspektifler arasındaki karşıtlığı yumuşatır; onun hem iyi ve hem de kötü olarak tanımlanması bu ayrım sayesinde anlaşılır. Yegâne iyinin erdem, yegâne kötünün de erdemsizlik olduğu Stoa etiğinde, bunların dışında kalan her şey farksız olarak nitelendirilir. Farksızlar da "doğaya göre (kata physin)" olmaları ve erdeme katkı sağlayacak şekilde kullanılmalarına göre "kabul edilen (eklegomenon)" ya da "tercih edilen (proēgmenon)" olarak adlandırılırlar (Stobaei, 1909, p. 7980). Yalnızca akıl sahibi varlıklar için geçerli olan bu ayrımlar, akıl sahibi olmayan varlıkların dürtülerinin kendinde iyi olmaları anlamına gelir. Zira genel olarak dürtü (hormē), ruhun bir şeye yönelik hareketidir ve doğaldır. Fakat dürtülerin farklılaşmasıyla oluşan tutkular (pathos) kökenleri itibariyle doğal olsalar bile, akla ve doğaya aykırı hareketler oldukları için akıl sahibi varlıklara özgü aşırılıklardır. Tutkuların ontolojisi söz konusu olduğunda dışsal bir uyarıcının etkisi altında kalan insan, bu uyarıcıya dair yargısı ve bunun sonucunda ortaya çıkan tutumu ya da etkinliği ile akla aykırı hareket etmiş olur. Burada tutku, uyarıcıya verilen tepkinin şiddetiyle ilgili bir uygunsuzluk olarak düşünülür. Söz gelimi birinin yürüme dürtüsüne göre yürüdüğünü varsaydığımızda, onun bacaklarındaki hareketin aşırı olmadığı söylenir. Fakat aynı kişi aynı dürtüye göre yürümek yerine koşmaya başlarsa, dürtüsüne dair yargısı yürümek değil koşmak olduğu için, tepkisinin şiddeti dürtüsüne uygun olmaz. Bu haliyle dürtüsünü aşırıya götüren 
insanda ortaya çıkan tutku, akli olanı aşar; doğaya yani doğal uyarıcıya uygun bir tepkiye karşılık gelmez (Long\&Sedley, 1987, 65J; 65T).

Epistemolojik açıdan düşünüldüğünde ise tutkuya göre eylemek, izlenime verilen yanlış onayın sonucudur ve onay ancak bir yargıya ilişkin olabilir. Bu nedenle Stoa felsefesinde bütün tutkular yargıdır ve insanın gücü dâhilindedir. Aşk bir olgu değil, yargı sorunu olarak ele alındığında, onun aslında "var olan" bir şey olmadığı açığa çıkar. vi Yargı ile olgu, dürtü ile tepki arasındaki uyuşmazlıktan doğan aşk, bir arzu (epithymia) türü olduğu için "beklenti (epibolē)" ile ilgilidir. Aşkın cinsi olan arzu, hâlihazırda bulunan bir varlığa ilişkin olan yargıya verilen onayın, o varlığa uygun olacağına dair akla aykırı bir beklentiyi ifade eder (Long\&Sedley, 1987, 65A). Bu beklentiye göre eyleme geçen kişi, duyulardan gelen izlenime yanlış bir onay verdiği için akla aykırı bir eylemi başlatmış olur. Bu şema dâhilinde düşünüldüğünde aşk, izlenime konu olan tekilin "güzel" olduğu yargısının akıl tarafından onaylanması ya da onaylanmaması ile ilgilidir. Eğer izlenime konu olan nesnenin fiziksel güzelliğine ilişkin bir onay veriliyor ya da nesnenin ruhunun güzelliği onaylanmıyorsa, ortaya çıkacak olan sanıda nesnenin niteliğine dair bir yanılgı ortaya çıkar. Bu yargıya (sanıya) göre eyleme geçen kişinin beklentisi cinsel birleşme olduğundan, onun dürtüsüne yönelik tepkisi aşırı ve doğaya aykırı olur. Fiziksel güzelliğe dayanan aşkın elde etmek istediği haz (hēdonē) ya da aşkın yaratabileceği kıskançlık (phthonos), ruhun ani (şimdide) çalkalanmalarına da neden olur (Laertius, 1931, VII. 111-114). Bu haliyle "kötü" aşkın anlık hazları hâlihazırdaki uyumu bozar; bunun yanı sıra aşk nesnesine yönelik bitimsiz arzu, sürekli bir huzursuzluk kaynağı olur ve gelecekteki ruh dinginliğini de yok eder. Bunun aksine kişi, yalnızca fiziksel olanın güzel olduğuna dair yargıyı reddeder ya da izlenime konu olan nesnenin ruhsal açıdan güzel olduğunu onaylarsa, bu kez izlenim doğru olur. Bu haliyle aşk bir tutku olmaktan çıkar ve o, dostluğu başlatabilecek bir dürtü olarak düşünülebilir. Dürtünün zamansallığı tutkuyu, nesnenin niteliği de aşkı belirliyorsa, sevme sanatına dair ayrıntıların güzelin özellikleri ve güzelden beklenene göre düşünülmesi gerekir. Bunun için "güzellik paradoksu" olarak adlandırılabilecek Stoacı akıl yürütmenin incelenmesi, aşkın doğasına dair oldukça aydınlatıcı sonuçlar çıkarmayı sağlayabilir.

\section{Güzellik Paradoksu}

Paradoxa Stoicorum'da yalnızca bilgenin özgür ve zengin olduğunu temellendiren Cicero, De Finibus'da bilgenin güzelliğinden de bahseder. Burada bir paradoks şeklinde ele alınmayan güzellik, bedenden çok ruha özgü bir özellik olarak düşünülür (1931, III. 75). Fakat Stoacılığa 
muhalif diğer yazarlar, Stoacıların güzellik ile bilgelik arasında kurdukları ilişkinin sağduyuya aykırı olduğunu düşünürler. Bilgenin "en çirkin olan olsa bile, en güzel olduğu" şeklinde ifade edilen paradoks (Arnim, 1964, III. 597), iki açıdan genel kanıya aykırı görünür. İlkin bu paradoks "sevilmeye değer olan (aksierastos) güzeldir, yalnızca bilge sevilmeye değerdir; o halde bilge güzeldir" şeklinde temellendirilen (Empiricus, 1936, XI. 170) akıl yürütmeyle birlikte ele alındığında, bilge zorunlulukla aşkın biricik nesnesi haline gelir. Bu sonuç Stoa felsefesinde bedenli birer nitelik olan iyi, doğru ve güzel gibi şeylerin yalnızca bilgenin ruhunda bedenlendiği; bütün bu iyilerin bilgeye mahsus olduğu düşüncesiyle de doğrulanır. Bunun yanı sıra bilge kendine özgü bilgisiyle, farksızları her zaman için uygun şekilde tercih eder. Güzel olan bilge, kendinde farksız olan aşkı, erdeme ve mutluluğa katkı sağlayacak şekilde kullanmasını da bilir. Fakat bilgenin aşk konusunda isabetli tercihleri, onu aşkın gerçek öznesi de kılar. Dolayısıyla Stoa felsefesinde güzelliğin sadece bilgede bulunması ile sevenin yalnızca bilge olması zorunlu olur. Aşk ile güzel, seven ile sevilen, sahip olmak ile peşinde koşmak arasındaki asimetriyi vurgulayan geleneksel kavramsallaştırmaların aksine, Stoa felsefesinde bu ikilikler gözden yiter; bilge hem seven hem de sevilen konumlarını dolduran "tuhaf" bir varlığa dönüşür.

Muhalif yazarlarca aşka dair tanımların ters yüz edilmesi anlamına gelen bu paradoksun içerdiği çifte çıkmaz, güzel olmaya aday ruhların peşinde koşan Stoacı bilgenin, "tutkusuz bir avcı" olarak düşünülmesiyle daha da çetrefilli bir hale gelir. Plutarkhos’a göre Stoacılar, aşkı "henüz erdeme ulaşmamış olmasına rağmen bu olanağı taşıyan bir gencin (meirakion) kovalanması (thēra)" olarak da tanımlarlar (1976, 1073b). Antikçağ'da kur yapmayı betimlemek için yaygın olarak kullanılan bu metaforda hem takip etmeyi hem de avını yakalamayı arzulayan avcı, avını sürekli gözetler (Dover, 1989, p. 87). Fakat Plutarkhos'a göre herhangi bir tutkunun bulunmadığı bir kovalamacaya aşk demek tuhaftır; zira avcının etkinliğini mümkün kılan, nesneye yönelik tutkusudur (1976, 1073c). Ayrıca bu ilişkide sevilen henüz bilge olmadığı için güzel de olamaz, bu da aşkın nesnesinin çirkin olduğu sonucuna yol açar. Haliyle tutkusuz bir avcının, çirkin bir ava ulaşmak için çabalaması oldukça tuhaftır. Paradoksun yol açacağı tuhaf sonuçlar, bununla da sınırlı değildir. Bilgenin seven değil de, sevilen olarak konumlandırıması halinde henüz erdeme sahip olmayan bir genç, "kocamış bir bilge" nin peşinde olacaktır. Fakat Sextus Empiciricus’un da belirttiği gibi "hiç kimse yaşlı birini sevmez" (1949; VII. 239). Çünkü Stoacılar aşkın, "filizlenen (hōra) gençlikle beliren (emphainomenon) güzellik aracılığıyla dostluk kurma çabası" olduğunu da söylerler (Stobaei, 1909, p. 115). 
Bilge seven olarak alındığında tutku olmaksızın aşkın nasıl olanaklı olabildiği ve çirkin bir gencin nasıl sevilebildiği; sevilen olarak alındığında ise gençlik çiçeği olmaksızın aşkın nasıl mümkün olabildiği cevaplanması gereken önemli sorular olarak ortaya çıkar. Bunun için tutkusuz avcının güzele yönelmesini sağlayanın ne olduğu, bu yönelimin nesnenin niteliğini nasıl belirlediği ve sevilen ile sevilmeye değer olan arasındaki ayrımın ne anlama geldiği incelenmelidir. Paradoksun çözümünü sağlayan ve Stoacı sevme sanatının pedagojik özelliklerini açığa çıkaran bu hususlar ise sevme erdemiyle yakından ilgilidir.

\section{Sevme Erdemi}

Stoacı sevme sanatı ve onun yetkinliği olan sevme erdemi birtakım kurallar içerir ve yaşamın belirli dönemleriyle net bir şekilde sınırlandırılır. Bu sanatta bilge bir seven olarak düşünüldüğünde ilkin sevilenin genç olması zorunludur; zira sevme sanatı "güzel" gençlere iyiyi ve erdemi kazandırmayı amaçlar. Bu sanatta, sevilen "sakal tıraşı olacak" yaştan küçük, "yirmi sekiz" yaşından da büyük olmamalıdır (Athenaeus, 1927, 563d-e). İnsan yaşamını yedi yıllık dönemlere (hebdomad) bölen Stoacılar, aklın "yedi" yaşından itibaren kullanılmaya başlandığını, "on dört" yaşında ise ön-kavrayışları (prolēpsis) edinmenin sona erdiğini ifade ederler (Arnim, 1964, II. 764; Stobaei, 1884, p. 317). Akla uygun eylemek ve erdemli olmak ise ancak "yirmi sekiz" yaşından itibaren gerçekten gerçekleşebilir. Bununla birlikte Plutarkhos'un aktardığı tanımda Stoacıların sevilen için meirakion sözcüğünü kullanmaları (1976, 1073b), onun yirmi bir yaşından küçük olmasını gerektirir. Zira meirakion, pek çok yazarda yirmi bir

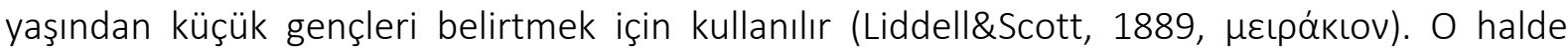
erdem öğrencisi on dört ile yirmi bir yaş aralığında eğitimine başlamalı ve yirmi sekiz yaşında öğrenciliğini sonlandırmalıdır. Bu uzun soluklu erdem eğitiminin ardından artık seven haline gelecek olan kişinin, sevme erdemi sayesinde bedende tezahür eden erdem olanağını görmesi beklenir.

Seven ile sevilen arasındaki ilişkide, sevilenin niteliğine ilişkin bu ölçütler, sevme sanatının pedagojik işlevini ortaya koyar. Sevilenin ancak "aklı erecek" yaşa geldiğinde öğrenci olabilmesi, erdem öğretmeninin tabi olduğu kuralları da anlamayı sağlar. Zenon, Khrysippos ve Apollodoros'a göre "bilge, doğası gereği erdeme yatkın olan gençlerde beliren (emphainomenon) görünüşü (eidos) sever" (Laertius, 1931, VII. 129). Bu ifade, "gençlikle beliren güzellik"i vurgulayan aşk tanımıyla birlikte ele alındığında, önemli olanın görünüş değil belirme olduğu anlaşılır. Buna göre seven, güzel bedenlere değil, bedende beliren güzele yönelmelidir. 
Zira burada bahsi geçen emphainomenon görünüşü değil, ruhsal güzelliğin bedendeki bulunuşunu imler. Stoa bedenselciliği ruhsal özelliklerin beden aracılığıyla duyumsanmasına olanak sağlar. Nasıl ki korktuğumuzda ya da utandığımızda, yüzümüz kızarıyor ya da soluyorsa (Arnim, 1964, І. 518), aynı şekilde ruhumuzun güzelliği de yüzümüze vurur. Zenon'a göre "kişinin karakteri görünüşünden (eidos) anlaşılır" (Laertius, 1931, VII. 173). Beden olmak bakımından farklılaşmayan ruh ve "beden" arasındaki sürekli etkileşim, güzel söz konusu olduğunda Platoncu çıkmaza dair kullanışlı bir çözüm de sağlar. Güzel ideasının tekil bedenlerde nasıl göründüğü, eş deyişle ideanın bir tekilde nasıl bulunduğu (parousia), Stoa bedenselciliğinde bir sorun yaratmaz. Hakiki güzele erişmek için kat edilmesi gereken Platoncu basamaklar burada söz konusu olmaz. Görünüş ile gerçeklik arasında bir ayrım olmadığı için bedensel ve ruhsal güzellik arasında bir çelişki de bulunmaz. Bu nedenle genç bedenlerde beliren ruhsal güzellik, aynı zamanda "erdemin filizlenen çiçeği (tēn hōran anthos aretēs)" (Laertius, 1931, VII. 130) olarak ifade edilir. Etiğin ve onun iyisi olan erdemin felsefenin meyvesi olmasına benzer bir şekilde, erdemli olmaya yatkın genç insanlar da bu meyvenin çiçeklendiği ruhlar olarak düşünülmektedirler.

Sevilenin yaşına ve doğasına ilişkin bu ölçütler, güzellik paradoksunda beliren ikinci tuhaflı̆̆ın çözüme kavuşmasını sağlar. Sevme sanatı aynı zamanda erdem eğitimi olduğu için, bu sanatın nesnesinin yetkin olmaması gerekir. Pedagojik aşk söz konusu olduğunda, erdemin yegâne taşıyıcısı olan bilgenin sevilen olması olanaksızdır. Bununla birlikte Sextus Empiricus'un aktardığı akıl yürütme hala geçerlidir ve Stoacı ayrımlarla da tutarlıdır. Burada sağduyuya aykırı olduğu düşünülen öncüller ve sonuç, Stoacıların neolojizmle suçlanmalarına neden olan titiz ayrımlarından kaynaklanır. Stoa etiğinde "seçilmeye değer olan (aireton)" ile "seçilen (aireteon)"in farklı olması gibi (Stobaei, 1909, p. 78), aşk söz konusu olduğunda da "sevilmeye değer olan (aksierastos)" ile "sevilen (erastos)" birbirinden farklılaşır. Bütün iyiler seçilmeye ve sevilmeye değer iken, yararlı olan (ōphelèma) her şey seçilir ya da sevilir. Bu ayrımlara göre farksız olan aşk ve onun nesnesi olan güzel genç, erdeme yatkınlığı nedeniyle sevilir; bilge ise iyiliğinden ötürü sevilmeye değerdir. Gencin günün birinde erdemi gerçekleştirme ihtimali dikkate alındığında, iyiliğe dönük bir yönelimin ve yararlı bir ilişkinin kurulduğu görülür. Eğer genç eğitimini başarıyla sonuçlandırırsa "sevilmeye değer" bir bilge haline gelir; artık aşkın yerini dostluğa bıraktığı bu ilişkide bilge, "iyi” aşkın hem seveni hem de sevileni olur.

Bedensel güzelliğin seveni harekete geçiren bir özellik olarak ifade edilmesi, sevme erdemine sahip bilge için bir çelişki içermez. Zira bedensel güzellik farksızdır, onu erdeme katkı 
sağlayacak şekilde kullanmasını bilen bilgedir. Bununla birlikte güzelliğin gençlerin bedeninde belirmesi, fiziksel çekiciliğe ya da cinsel arzuya işaret etmez. Nitekim tekilin güzelliği çoğu zaman işlevine uygunlukla birlikte düşünülür. Ksenophones'in Şölen'inde çirkinliğiyle ünlü Sokrates'in erkek güzeli Kritoboulos ile güzelliğini yarıştırması sırasında, gözlerinin ayrıklığını görüş açısının genişliğiyle ilişkilendirmesi (1997, V. 4-6) gibi, Stoacılar da güzel olanın kullanışlı (khrēsimon) ve faydalı (sympheron) olduğunu belirtirler (Stobaei, 1909, p. 100). Bunun yanı sıra Cicero'nun da ifade ettiği gibi gençlerde erdemin tezahürü hoşgörü dolu niteliklerde kendini gösterir; bu niteliklerin bir görüntü sanılıp yadsınması yanlıştır $(2014$, I. 46).

Sevme sanatında, bilgeyi etkinliğe yönlendiren izlenim bedene dayanmadığı için burada bir tutku bulunmaz. Babamızı öldüren ya da annemize tecavüz eden birine yönelik tepkimizin öfkeye değil, evlatlık görevine dayanması gibi (Seneca, 1928, I. 12), sevenin harekete geçmesini sağlayacak şey de haz ya da arzu değildir. Zira "Erdemli insanlar ne kendilerinde ne de başkalarında da hazzı kabul etmedikleri için serttirler (austēros)" (Laertius, 1931, VII. 117). O halde sevme sanatının öğretmeni ne kendinde ne de öğrencisinde tutkuların yerleşmesine izin verir. Bilge her koşulda sakin ve serinkanlıdır (Seneca, 1917, 59. 16). Bununla birlikte tıpkı aşk gibi bir farksız olan cinsel ilişki söz konusu olduğunda onun kendinde kötü olmadığı da ifade edilir. Doğuştan gelen ve ruhun bir bölümünü oluşturan üreme yetisi, canlı varlıkların doğal eğilimlerinin bu yönde olduğunu gösterir. Bilge için cinsel ilişki tutkuyla ilgili bir etkinlik olmadığından, erdemli yaşama katkı sağladığı oranda tercih edebilecek olan bir farksızdır (Stobaei, 1909, p. 115). Bu haliyle cinsel ilişkinin pedagojik aşkta yeri yoktur; zira sevilen henüz erdemi edinmemiş ve tutkuları ruhundan tamamen söküp atamamıştır. Yine burada sevenin tutku içeren herhangi bir ilişkide bulunması da olanaksızdır. Bunun yanı sıra dostluğu elde etmek amacıyla kurulan aşk ilişkisinde, sevenin güdüsü akla aykırı değildir. Burada seven, sevilenin günün birinde erdemli bir insan olacağına yönelik beklentiyle eyler ve bu beklenti bilgenin ancak bilgeyle dost olabileceği anlayışına (Laertius, 1931, VII. 124; Stobaei, 1909, p. 108) dayanır.

Bilgenin güzel olmaya aday ruhlara yönelik dürtüsü, bilgeliğinin gereğidir; bu durum sevme sanatını bilimle, sevme erdemini de bilgiyle ilişkilendirmek anlamına gelir. Stoacılar bilgenin eylemlerinde makul ve diyalektik açıdan kusursuz olduğunu belirttikten sonra, onun şölenlerde nasıl davranması ve nasıl sevmesi gerektiğini bilen olduğunu da eklerler (Stobaios, 1909, p. 65). vii Sevme sanatının yetkinliği olan sevme erdemi, şölenlerde ve aşk konularında ortaya çıkar. Sevme erdeminin bilgisine sahip olan insan, katıldığı şölenlerde ne kadar içmesi, 
ne kadar konuşması ve ne zaman ayrılması gerektiğini bilir. Bir şölen sırasında neden böyle sessiz sedasız oturduğunu soranlara, burada susmasını bilen birinin bulunduğunu söyleyen Zenon (Laertios, 1931, VII. 24), sevme erdemini ölçülülükle birlikte düşünür. Zaten Zenon’a göre aşkın konusu olan güzel, "ölçülülüğün çiçeği (sōphrosynēs anthos)”dir (Laeertios, 1931, VII. 23). Her ne kadar Stobaios sevme erdemini ölçülülüğün alt türlerinden biri olarak anmasa da, ölçülülüğün dürtüyle ilgili olduğunu açıkça belirtir (1909, p. 60). Seçilmesi ve kaçınılması gereken şeylerin bilgisi olan ölçülülük, farksız olanların kullanımıyla ilgili olan birincil erdemlerdendir. Şölenlerde uygun davranışın ne olduğunun bilinmesi sevme erdemini ölçülülükle ve ölçülülüğün türü olan edep (kosmiotēs) ile birlikte düşünmeyi sağlar. Uygun ve uygun olmayan hareketin bilgisi olan edep, ruhun doğal olmayan hareketlerini önlemeyi sağlar (Stobaei, 1909, p. 61). Bununla birlikte genel olarak ölçülülük, yalnızca arzunun değil bütün tutkuların dışlanmasını gerektirir. Bu haliyle haz, acı ve korku, en az arzu kadar ölçülü insanın ruhundan sökülüp atılması gereken kötülükler olarak düşünülür. Dahası hazzın -arzudan farklı olarak- şimdiye ilişkin bir aşırılık olarak düşünülmesi, sevme erdeminin özel bir tutkuya, hazza karşıt olarak da düşünüldüğünü gösterir. Zira şölenlerde sergilenmesi gereken uygun tutum, canlı izlenimlere onay vermemek yani yemeye ve içmeye ilişkin anlık bir kontrol ise, sevme erdemi burada haz düşkünlüğüne karşı olan ölçülülüğün alt türleriyle ilişkilendirilmiş olmalıdır.

Sevme erdeminin şölenlerdeki işlevi ölçülülükle ilgili olsa da, o bundan ibaret değildir. Şölenlerde sergilenmesi gereken tutumlara ilişkin bilgiden başka, "güzel/uygun aşkın tümel bilgisi (katholou epistēmēn toū kalōs eran)" de sevme erdemiyle ilgilidir. Ayrıca erdeme yatkın gençlerin nasıl avlanacağı ve onları erdeme teşvik etmek için gerekli olan bilgiler de sevme erdeminin konuları arasında sayılmaktadır (Stobaei, 1909, p. 65-66). Burada yinelenen avcılık metaforu, sevme erdemini başka bir kardinal erdemle ilişkilendirmeye olanak sağlar. Sevme sanatını betimlemek üzere kullanılan Stoacı avcılık sanatı, geleneksel imgede içerilen özelliklerden farklılaşır. Metaforun gözetlemeye ilişkin kullanımı isabetli olsa da, Stoacı avcının avını gözetlemekle kalmadığı, onu sürekli gözettiği de görülür. Bu noktada avcılıktan çok çobanlığı andıran "gözetme" özelliğinin, avcılıkla nasıl ilişkilendirileceği sorulabilir. Bu soruya bir cevap verebilmek için ilkin çobanlıkta asla ortadan kalkmayacak olan hiyerarşik ilişkinin, Stoacı sevme sanatıyla ilişkilendirilemeyeceği vurgulanmalıdır. Nitekim güzel ruhlardaki erdem olanağından yola çıkan bu sanat, dost kazanmaya yönelir; dostluğun olduğu yerde de "gütme" ve "güdülme" bulunmaz. İkinci olarak Stoacı avcılığın, tıpkı balıkçılıkta olduğu gibi uygun mevsimi beklemeyi ve doğru araçlarla avlanmayı içerdiği eklenmelidir. Seven ile sevilen 
arasındaki asimetrik ilişkide, avın seçilmesi yukarıda ifade edilen kurallara bağlıdır ve seven pedagojik ilişki süresince sevileni teşvik (protreptikos) etmek zorundadır. Erdeme yatkın olan gencin, eğitime başlaması için "kulaklarından yakalanması"; ruhunu kirletecek şeylerden uzak durması için ikna edilmesi gerekir (Laertius, 1931, VII. 24). Eğitim başladığında ise genci erdem yolundan alıkoyacak genel ayartıcılar ve gencin doğasından kaynaklanan özel durumlar dikkate alınmalıdır.

Bununla birlikte yine de avcılık metaforunun Stoacı sevme sanatını tam anlamıyla karşılamadığı söylenebilir. Nitekim avcının yaşama kast ederken uyguladığı şiddet ve avcılığın yalnızca avcıya olan yararı, sevme sanatında içerilen çifte yararı, eş zamanlı dönüştürücülüğü ve ulaşılması gereken amacı bulanıklaştırır. Bu sanatı ve erdemi belirginleştirmek için kaynaklarda bahsi geçmeyen başka bir metafor kullanışlı olabilir. Sevme sanatı tanımlarında ısrarla vurgulanan "çiçek" ve "tomurcuk" metaforları, Stoacı bilgenin adeta bir "bahçıvan" gibi düşünüldüğünü gösterir. Bahçıvanın iyi tohumu kötü tohumdan ayırmayı bilmesi; yabani otları düzenli bir şekilde ayıklaması; çiçekleri için uygun gübreyi, doğru ışığı ve yeterli miktarda suyu temin etmesi Stoacı bilgenin bir pedagog olarak nasıl davrandığını anlamayı sağlar. Dahası bahçıvanın tecrübesi ve emeği yalnızca güzel çiçeklerin açmasına neden olmaz; kuşkusuz burada bazı çiçekler daha açmadan solacak, bazıları ise bakım gerekmeksizin kendiliğinden açacaktır. Dolayısıyla bahçıvanın sanatı her zaman doğaya hükmedemeyecektir. Fakat yine de açan her çiçekle birlikte bahçıvan da dönüşecek, hele ki toprak baştan sona güzel çiçeklerle bezendi mi, o artık toprak olmaktan çıkıp büsbütün bahçe olacaktır.

Bu haliyle sevme erdemi, uygun aşkın tümel bilgisini, sevilenin doğasına (oikeios) uygun şekilde kullanmayı içerir. Yaşama sanatına ilişkin performatif metaforlardan farklı olarak burada, bahçıvan ile çiçek arasındaki örtüşmezlik, yaşama sanatında ima edilen bireyselliği ortadan kaldırır. Bu haliyle sevme sanatında, yaratan ile yaratılanın ilkesinin farklılığı, etkinlikle ereğin örtüşmesi halinde dostluğun ortaya çıkmasını sağlar. Bu durum ise sevme erdemini adaletle birlikte düşünmeyi mümkün kılar. Stoa etiğinde bölüştürmeyle ilgili bir erdem olarak düşünülen adalet, şeylerin uygun şekilde dağıtılmasının bilgisi olarak tanımlanır (Stobaei, 1909, p. 61). Bu haliyle adalet amacını kendinde taşıyan bir iyi olsa da, bir başkasıyla olan ilişkide ortaya çıkar. Bireyselliğin ötesine uzanan adaletin türlerinden biri olan "paydaşlık (eukoinōnēsia)" ise sevme erdemiyle ilişkilidir. "Bir toplumdaki eşitliğin bilgisi (epistēmē isotētos en koinōnia)" (Stobaei, 1909, p. 62) olan bu erdem, eşit paylaştırmayı ima ettiği kadar, eşit yurttaşların ilişkisini de içerir. Marcus Aurelius'un insan doğasının temel niteliklerinden biri olarak atıf yaptığı paydaşlık, 
kozmopolitanizm idealini temellendirmeye yarar ve aşkla değil akrabalıkla birlikte anılır (1930, XI. 20). Bununla birlikte erken dönem düşüncede paydaşlık, eşit ve gerçek yurttaşların yani birbirleriyle dost olan bilgelerin "ortak iyi" den eşit ölçüde yararlanmalarını ifade eder. Zira bütün iyiler, yalnızca erdemli insanlar yani gerçek dostlar arasında ortaktır; bununla birlikte dostlar arasında ortaya çıkan uyum (homonoia), ortak iyilerin (koinōn agathōn) bilgisidir. Ne var ki Platon'un “dostlar arasında ortak olan şeyler”i $(1958,449 c)$ Stoacıların ortak iyilerine karşılık gelmez. Her ne kadar kadınların ve çocukların ortaklığı Zenon'un Devlet'inde yer alan konulardan biri olarak sayılsa da, burada herhangi bir cinsellik politikası iması bulunmaz. Platon'un nüfus ve doğum politikalarının temelini oluşturan ortaklık düşüncesinin Stoacı dostlukla bir ilgisi yoktur. Schofield'in da belirttiği gibi ortak iyiler erdeme ve erdemli eylemlere yol açan yararlı farksızlardır (1999, p. 97). Bu haliyle erdeme yatkın gençlere duyulan pedagojik aşkın farksızlığı, erdeme ve uyuma katkı sağladığı için yararlıdır.

Sevme sanatı güvenilir (pistos) ve istikrarlı (bebaios), dışsal zorunluluktan ve sanılardan uzak olan gerçek dostluğun da teminatıdır (Stobaei, 1909, p. 101; 108). Dışsal belirlenimlerden bağımsız olan, bu nedenle tutkuların ve sanıların kölesi olmayan dostlar, "kaçınılacak ve istenilecek olanın bilgisi"ne ve "kendinde olanı yapma gücü"ne" sahiptirler (Arnim, 1964, IV: $\varepsilon \dot{\varepsilon} \lambda \varepsilon \cup \theta \varepsilon \rho i \alpha)$. Bu haliyle bilge dostların sahip oldukları en yüce şey, irade gücüdür (ipsius voluntas) ve onların özgürlüğü istedikleri gibi yaşama gücüne (potestas vivendi ut velis) sahip olmalarından kaynaklanır (Cicero, 2012, XXXIV). O halde bilgenin aşk ilişkisinden beklentisi dostluk olduğu ve dostluk da "iyi aşka" karşılık geldiği için, pedagojik aşkın toplumsallığı amaçlaması, bilgeler toplumunda uyumun, istikrarın, iyinin ve özgürlüğün açığa çıkmasına katkı sağlar. Pedagojik aşktan politik aşka uzanan sevme sanatı ve onun erdemi, bireyselliği toplumsallığa genişletirken dostlarla iyileri paylaşma sevincini (khara) de mümkün kılar.

\section{Sonuç}

Stoacı bilgenin dürtülerine hâkim ve yargılarında makul oluşu, yaşama sanatının etikle çevrelenmiş bir bireysellikten ibaret olduğu yargısının temel dayanağını oluştururken, yaşama sanatını kendilik ile ilişkilendiren çalışmalar da bunu pekiştirmiş görünmektedirler. Yaşama sanatıyla ilgili olarak vurgulanan bütün bu özellikler, felsefenin bütün disiplinlerini etiğe tabi kılar görünse de dostluğu amaçlayan sevme sanatının toplumsal özgürlük ve istikrara yönelik çabası, bu konuda Stoacılığa yöneltilmiş olan eleştirilere şüpheyle yaklaşmayı sağlar. 
Bütün bunlardan hareketle Stoa etiğinin tutkusuzlukla işaretlenen çiğ bir ahlakçıllğa indirgenemeyeceği belirtilmelidir. Felsefe, sevme sanatı olarak düşünüldüğünde ya da yaşama sanatının sevme sanatından bağımsız olmadığı fark edildiğinde, Stoacılığı etiğe vakfedilmiş bireysel ve soyut tasarımlardan; Stoacıları da çileci ve kölece bir ahlakın vaizlerinden ibaret görmek olanaksızlaşır. Stoacı sevme sanatı pedagojik ve politik işlevleriyle, yaşama sanatında ima edilen bireyselliğin ötesine geçmeyi sağlar. Öznelerarası olan bu sanat, kendine özgü erdemiyle ruhu çalkalandıran tutkuları çözümlemeyi salık verirken insanın bir duygu varlığı olduğunu da göz ardı etmez. Zira insani duygular, ruhtan sökülüp atılması gereken tutkulardan ibaret değildirler. Stoacılar dört temel tutkuya karşılık üç hoş duygulanımın (eupatheia) bulunduğunu; sevinç, rıza ve ihtiyatın doğaya uygun bir yaşamın sonucunda ortaya çıkan hoşluklar olduğunu vurgulamayı ihmal etmezler. Bu haliyle tutkusuzluktan anlaşılan, mutlu bir yaşamı mümkün kılan dinginlik ve buna eşlik eden hoş duygulanımlar ise bunun kendinde "çiğ" olduğunu ileri sürmek, ne yaşama sanatında ne de sevme sanatında vurgulanan asli amaçlara uygun olacaktır.

Son tahlilde bilgece yaşama sanatı ve bilgelerin devletine yurttaş kazandırmaya yarayan sevme sanatı adil, özgür ve düzenli bir toplum için elzemdir. Yaşama sanatının bireyselliği nedeniyle kuşkulu görünen yönünü, politik aşka yönelmesiyle ortadan kaldıran sevme sanatı, etiği politikaya bağlar. Helenistik dönemde etik ile politikanın birbirinden ayrı alanlar olarak düşünüldüğüne ilişkin yaygın iddia, kozmopolitanizmi yurtsuzluğu müjdeleyen bir biçimsellik (belirlenimsizlik) olarak görmekten kaynaklanır. Fakat Stoacıların düşünme ve eylem ilkelerini ortak akla dayandırmaları, yurttaşlığı yalnızca akılla temellenen bir konum olarak düşündükleri anlamına gelmez. Akıl iyi yaşam için bir ölçüt ve akrabalığın temeli olsa bile, akıl sahibi olmak herkesi ideal devletin yurttaşı kılmaz. Bu ise kozmopolitanizmin biçimsel, onda içerilen özgürlüğün de soyut olmadığını gösterir. Bilakis erken dönem Stoacıların yaşama ve sevme sanatı olarak düşündükleri felsefe, somut ilişkilerle biçimlenmeyi ve biçimlendirmeyi içerir. Gelişen ve yetkinleşen insanların, güvenlikten ve özgürlükten taviz vermeksizin bir topluluk oluşturmaları mümkünse, bu, bir bütün olarak erdeme ve özellikle sevme erdemine bağlıdır. Burada ölçülülük ile adaleti birlikte düşünmeyi sağlayan sevme erdemi, ölçülü ve adil olan özgür insanların ortak iyilerden "eşit" ölçüde pay aldıkları uyumlu, istikrarlı ve özgür bir toplumu mümkün kılan bir yetkinliktir. Ve belki de dostluğu amaçlayan bu yetkinlik erken dönem Stoa etiğinin en politik yanıdır. 


\section{ORCID ID}

\section{MELIKE MOLACI}

\section{Declaration of Conflicting Interests}

The author declared that there were no conflicts of interest with respect to the authorship or the publication of this article. https://orcid.org/0000-0002-8128-7706

\section{Çıkar Çatışması Beyanı}

Yazar bu makalenin yazarlık veya yayımlanmasına ilişkin olarak hiçbir çıkar çatışması olmadığını beyan etmiştir.

\section{KAYNAKÇA}

Aristoteles. (1995). Retorik. (M. H. Doğan. Çev.). İstanbul: Yapı Kredi Yayınları.

Aristotle. (2007). Posterior Analytics. Topica. (H. Tredennick. Trans.). Cambridge: Harvard University Press.

Arnim, H.V.A. (1964). Stoicorum Veterum Fragmenta Vol. I-IV. Stuttgart: Teubner.

Athenaeus. (1927). The Deipnosophists. (C. B. Gulick. Trans.). Cambridge: Harvard University Press.

Aurelius, M. (1930). Marcus Aurelius. (C. R. Haine. Trans. \& Ed.). Cambridge: Harvard University Press.

Bett. R. (2010). Beauty and its relation to goodness in Stoicism. Ancient Models of Mind. (A. Nightingale \& D. Sedley, Eds.). Cambridge: Cambridge University Press, 130-152.

Celkyte, A. (2017). The Stoic Definition of Beauty as Summetria. The Classical Quarterly, 67(1), 88-105. doi:10.1017/S0009838817000386.

Cicero, M.T. (1931). On Ends, (H. Rackham. Trans.). Cambridge: Harvard University Press.

Cicero, M.T. (1967). Academica. (H. Rackham. Trans.). Cambridge: Harvard University Press.

Cicero, M.T. (2012). Stoacıların Paradoksları. (S. G. Kalaycıoğulları \& C. Keyinci. Çev.). Ankara: İmge Kitabevi.

Cicero, M. T. (2014). Yükümlülükler Üzerine. (C. C. Çevik. Çev.). İstanbul: Türkiye İ̧̧ Bankası Kültür Yayınları.

Cornutus, L. A. (2018). Greek Theology, Fragments, and Testimonia. (G. Boys-Stones. Trans \& Ed.). Atlanta: SBL Press.

Deleuze, G. (2015). Anlamın Mantığı. (H. Yücefer. Çev.). İstanbul: Norgunk Yayıncılık.

Dover, K. J. (1989). Greek Homosexuality. Cambridge: Harvard University Press.

Empiricus, S. (1933). Outlines of Pyrrhonism. (R.G. Bury. Trans.). Cambridge: Harvard University Press.

Empiricus, S. (1936). Against Physicists, Against Ethicist. (R. G. Bury. Trans.). Cambridge: Harvard University Press.

Empiricus, S. (1949). Against Professors. (R. G. Bury. Trans.). Cambridge: Harvard University Press. 
Epictetus. (1998). Discourses Books 1-2. (W. A. Oldfather. Trans.). Cambridge, Harvard University Press. Epiktetos. (2019). Enkheiridion. (C. C. Çevik. Çev.). İstanbul: Türkiye İş Bankası Kültür Yayınları.

Foucault, M. (2010). Cinselliğin Tarihi. (H. Tanrı̈̈ver. Çev.). İstanbul: Ayrıntı Yayınları.

Foucault, M. (2015). Öznenin Yorumbilgisi. (F. Keskin. Çev.). İstanbul: İstanbul Bilgi Üniversitesi Yayınları. Galen. (2005). On the Doctrines of Hippocrates and Plato. (P. De Lacy, Trans. \& Ed.). Berlin: AkademieVerlag.

Hadot, P. (2011). İlkçağ Felsefesi Nedir? (M. Cedden. Çev.). Ankara: Dost Kitabevi.

Hadot, P. (2012). Ruhani Alıştırmalar ve Antik Felsefe. (K. Gürkan. Çev.). İstanbul: Pinhan Yayıncılık.

Heraclitus. (2005). Heraclitus, Homeric Problems, (D. A. Russell \& D. Konstan, Trans. \& Ed.). Atlanta: SBL Press.

Jedan. C. (2009). Stoic Virtues: Chrysippus and the Religious Character of Stoic Ethics. London: Continuum International Publishing Group.

Lactantius. (1890). "The Divine Institutes" in The Writings of the Fathers down to A. D. 325 The AnteNicene Fathers Vol VII. (A. Roberts \& J. Donaldson. Trans.). New York: The Christian Literature Company.

Laertius, D. (1931). Lives of Eminent Philosophers Books 6-10. (R. D. Hicks. Trans.). Cambridge: Harvard University Press.

Liddell, H. G. \& Scott, R. (1889). An Intermediate Greek-English Lexicon. Oxford: Clarendon Press.

Long. A. A. \& Sedley, N. D. (1987). The Hellenistic Philosophers, Cambridge: Cambridge University Press.

Lucretius. (1992). On the Nature of Things. (W. H. D. Rouse. Trans.). Cambridge: Harvard University Press.

Musonius (1905). C. Musonii Rufi Reliquiae, (O. Hense. Ed.). Leipzig: Teubner.

Nietzsche, F. (1968). The Will to Power. (W. Kaufmann \& R. J. Hollingdale. Trans.). New York: Vintage Books.

Nietzsche, F. (2010). Yunanlıların Trajik Çağında Felsefe Bir Polemik. (T. Erdem. Çev.). İstanbul: Arya Yayıncilık.

Nussbaum, M. C. (1996). The Therapy of Desire. New Jersey: Princeton University Press.

Nussbaum M. (1998) Eros and the Wise: The Stoic Response to a Cultural Dilemma. The Emotions in Hellenistic Philosophy. The New Synthese Historical Library. (J. Sihvola \& T. Engberg-Pedersen. Eds.). doi.org/10.1007/978-94-015-9082-2_10.

Pearson, A. C. (1891). The Fragments of Zeno and Cleanthes. London: Cambridge University Press.

Plato. (1925). Statesman. Philebus. Ion. (H. N. Fowler \& W. R. M. Lamb. Trans.). Cambridge: Harvard University Press.

Platon. (1958). Devlet. (S. Eyüboğlu \& M. A. Cimcöz. Çev.). İstanbul: Remzi Kitabevi.

Platon. (2014). Şölen. (E. Çoraklı. Çev.). İstanbul: Alfa Yayınları. 
Platon. (2019). Phaidros. (A. Çokona. Çev.). İstanbul: İ̧̧ Bankası Kültür Yayınları.

Plutarch. (1976). Moralia Volume XIII: Part 2. (H. Cherniss. Trans.). Cambridge: Harvard University Press.

Price. A. W. (2002). Plato, Zeno, and the Object of Love. The Sleep of Reason. (M. Nussbaum \& J. Sihvola.

Eds.). Chicago: The University of Chicago Press, 170-199.

Schofield, M. (1999). The Stoic Idea of the City. Chicago: The University of Chicago Press.

Sellars, J. (2009). The Art Of Living: The Stoics on the Nature and Function of Philosophy, London: Bloomsbury Publishing.

Seneca, L. A. (1917). Epistles 1-65. (R. M. Gummere. Trans.). Cambridge: Harvard University Press.

Seneca, L. A. (1925). Epistles 93-124, (R. M. Gummere. Trans.). Cambridge: Harvard University Press.

Seneca, L. A. (1928). Moral Essays Vol I. (J. W. Basore. Trans.). Cambridge: Harvard University Press.

Stobaei, I. (1884). Anthologium, Volume 1. (C. Wachsmuth \& O. Hense. Ed.). Berlin: Apud Weidmannos.

Stobaei, I. (1909). Anthologium, Volume 2. (C. Wachsmuth \& O. Hense. Ed.). Berlin: Apud Weidmannos.

Xenophon. (1997). Symposium. (O. J. Todd. Trans.). Cambridge: Harvard University Press.

\title{
Sonnotlar
}

\begin{abstract}
' Stoacıların felsefeyi yaşama sanatı (tekhne peri ton bion / ars vitae / ars vivendi) olarak adlandırdıklarına dair pek çok kaynak bulunmaktadır. Bkz. Arnim, 1964, III. 598; Cicero, 1931, I. 42; III. 4; IV. 19; 1967, II. 23; Empiricus, 1933, III. 188-249; 1936, XI. 170; Seneca, 1925, 95.7-9; Stobaei, 1909, p. 63.

i" Çağdaş yazarların Stoacı pratiklere dair çözümlemeleri için bkz. Foucault, 2010, s.309-490; 2015; Hadot, 2011, s, 97-171; 2012; Nussbaum, 1996, p. 316-483; Sellars, 2009. Ayrıca Stoacıların yalnızca öznel pratikleriyle değil felsefi kavrayışlarıyla da farklı tür bir filozof imgesini açığa çıkardığını iddia eden Deleuze'ün Stoacı "sapkın”lığa ilişkin çözümlemeleri için bkz. Deleuze, 2015, s. 148-154; 162-173.
\end{abstract}

iii Estetiğin ve güzelin anlamıyla ilgili çağdaş çalışmalar için bkz. Bett, 2010, p. 130-152; Celkyte, 2017; Jedan, 2009; Nussbaum, 1998; Price, 2002, p. 170-199; Schofield, 1999.

iv Roma toplumundan evliliğin yüceltilmesi De Natura Rerum'da gerekçeleriyle birlikte açıklanır (Lucretius, 1992, IV. 1185-1280; V. 1009); ayrıca evlilik ve cinsellik Stoacı Musonius Rufus'un derslerinde de ele alınır (Musonius, 1905, p. 63-70). Fakat Roma'da evliliğe yapılan övgülerin sevme erdemiyle ilgisiz olmasının gerekçesi, evliliğin heteronormatif oluşu değil, sevme sanatında içerilen kuralların ve sınılların evlilik ilişkisinde geçerli olmamasıdır. Zira Stoacılar kadınların da erdeme yatkın olduğunu savundukları (Lactantius, 1890, III. 25; Musonius, 1905, p. 89) için seven-sevilen ilişkisinde kadınların her iki konumu da doldurabileceklerini düşünürler. Dolayısıyla Stoacı aşk ilişkisinde hemcins olmak bir koşul değildir, bunun en açık kanıtı da Stoacı alegorist Herakleitos'un sevenlere örnek olarak Akhilleus, Oddysseus, Penelope, Aias ve Nestor gibi örnekleri anmasıdır $(2005,78.3)$.

` Seneca'nın aşka dair tutumu, öfkeye dair tutumuna koşut olduğu için tutkulara dair yaklaşımını Öfke Üzerine adı kitabından çıkarsamak mümkündür. Bunun yanı sıra Seneca, ölçüsüz olan aşkın, kıskançlık ve öfkeyle birlikte insanı ve çevresindekileri nasıl yıkıma sürükleyeceğini Medea aracılığıyla gözler önüne serer. Seneca'nın Medea'sının Stoacı tutkular kuramı bağlamında değerlendirilmesi için ayrıca bkz. Nussbaum, 1996, p. 439-483.

vi Tutkuların "ontolojik" açıdan yoklukları Stoa fiziğinin temel ayrımlarına dayanır. Buna göre yargılar, önermeler, yüklemler vb. ifadeler birer lekton'dur ve lekton var olmayan (bedensiz) bir gerçeklik olup, var olan bedenlerle nedensel bir ilişki kuramaz.

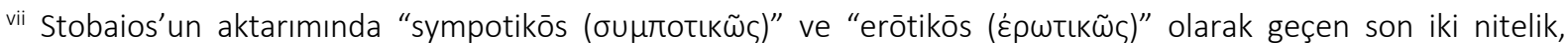
"şölensel" ve "erotik" olarak tercüme edilebilir. Fakat bu çalışmanın bağlamı açısından düşünüldüğünde, bu kullanımlar karışıkığa neden olabileceği için tercih edilmemiştir. 